\title{
Human Rights and Socialculture: An Exploration
}

\author{
Manoj Kumar Choudhary ${ }^{*}$ \\ Department of Education, Shri ram College, MZN, India \\ *Corresponding author: manojchoudhary1000@rediffmail.com
}

Received October 13, 2014; Revised October 24, 2014; Accepted November 17, 2014

\begin{abstract}
Social culture is critical to just about every area of society. The right to culture is meant to secure individual access to the cultural framework dominating the public institutions that have the authority to deliberate, interpret, and enforce human rights. This is made possible through the acquisition of the suitable "cultural equipment" mentioned in the first part of the paper. Such acquisition is a prerequisite for the exercise of the right to cultural participation as well as a range of other individual rights and freedoms similarly recognized inhuman rights law, from this viewpoint, the aim of the article is to focus on the concept of culture and its place in human rights law. This interdisciplinary theoretical understanding of the concept of "culture" serves to redirect attention towards a range of issues that have long been marginalized, but which warrant culture a central place in human rights research and on the international human rights agenda. As a consequence, the main argument developed throughout this paper consists in a summon for the human rights agenda on culture to reaffirm the universal and overarching importance of culture in advancing respect for human rights and to seek to rebalance the present agenda dominated by a right to cultural identity with an urgent emphasis on the fundamental importance of "Cultural equipment" and cultural infrastructure for individual freedom.
\end{abstract}

Keywords: peoples, culture, human rights, society, minorities

Cite This Article: Manoj Kumar Choudhary, "Human Rights and Socialculture: An Exploration.” American Journal of Educational Research, vol. 2, no. 11 (2014): 1069-1075. doi: 10.12691/education-2-11-11.

\section{Introduction}

Social culture talk in human rights and diplomatic circles emerged at the beginning of the 1990s in reaction to three rather different events: the ethnic revivals in postcommunist politics with their corollary demands for national independence and self-determination, the partial success of indigenous people in establishing their own distinct human rights agenda, as well as the criticism of the claim about the universal validity of human rights advanced in the World Conference on Human Rights in Vienna in 1993 and reflected at least to some extent in its concluding document.

While these events evidently boosted a sense of urgency to give culture a firm place in human rights research, it must be noted that the issue of culture was not novel, but had surfaced already at the time of the adoption of the Universal Declaration of Human Rights in 1948. At that time, however, the social cultural critique came from academic circles and was most forcefully expressed in the "American Anthropological Statement" submitted to the drafters of the Declaration. The American anthropologists underlined a series of principles as being crucial:

\section{Role of Social Culture}

\subsection{Personality Developing}

Social culture is the path for an individual to develop his personality and for this reason respect for individual differences involves a respect for cultural differences;
The scientific fact that no technique of qualitatively evaluating cultures has been discovered validates the "respect for differences between cultures" thesis;

\subsection{Value Related Role}

Standards and values are relative to the social culture from which they derive so that any attempt to formulate postulates that grow out of the beliefs or moral codes of one culture must to that extent detract from the applicability of any Declaration of Human Rights to mankind as a whole.

Nonetheless, as the pressing purpose of the declaration was to condemn the atrocities of the Second World War, the somewhat abstract and haughty propositions about the tie between individual human beings and particular cultures listed in the anthropologists. Statement did not receive much attention and when it did, the final inclusion of a provision on culture was motivated by a proclaimed importance of individual participation in the cultural life of the community.

Since the adoption of the Universal Declaration of Human Rights, a number of culture-related interests and concerns have been introduced and incorporated into the fabric of international human rights law.

\section{Relationship between Social Culture \& Human Rights}

For this reason, the aim of the paper consists in examining the relationship between culture and respect for 
human rights, revealing culture as a quality possessed by the individual with a serious impact on its ability to enjoy the rights and freedoms as recognized in international human rights law in meaningful and effective ways. This understanding serves to redirect attention towards a range of issues that have long been marginalized, but which warrant culture a central place in human rights research and on the international human rights agenda.

\subsection{Significance of Culture in Human Rights Laws}

The claim about the critical role and significance of culture in human action is familiar to social theorists and anthropologists, being known as the subjectivebehavioural approach that understands culture, "not merely as an inner state (feelings and experience), but also as a vehicle for commitments, utterances, and actions." 6 Moreover, it is consented that the individual's cultural resources language and other skills (cultivated through education and training), informal know-how, familiarity with local habits, styles, and customs-reflect whether a person is sufficiently equipped in cultural terms to enjoy and exercise fully his or her agency and freedom. As An Swindler states:

"Culture shapes action, not by providing ultimate ends, but by providing a repertoire or tool-kit of habits, skills and styles from which people construct strategies of action. It consists of symbolic vehicles of meaning, including beliefs, ritual practices, art forms, and ceremonies, as well as informal cultural practices such as language, gossip, stories, and rituals of daily life.”

\subsection{Legal Perspective of Culture}

It is generally considered that, from a legal perspective, culture is first and foremost a "quality possessed by the individual that directly influences the ability to enjoy the rights and freedoms as recognized in international human rights law in effective and meaningful ways.” In this line of thought, Jessica Almqvist notes in Human Rights, Culture, and the Rule of Law that the cultural dimension of the individual is represented by three elements: skills (cultural equipment); cultural norms (Adiaphora); and ideology (comprehensive doctrine).

\section{Historical Background of Culture\& Human Rights:}

\subsection{Pre Cold Bar Culture}

The skills, norms, and ideological outlook which together constitute the cultural dimension of the individual are generally understood as the product of membership in society. And from this angle, the cultural dimension is primarily acquired and learned. One classic definition of culture was provided by Edward Tylor in 1871 considering it as being "that complex whole which includes knowledge, belief, art, law, morals, custom, and any other capabilities and habits acquired by man as a member of society."

In addition to being acquired and learned, culture is also generally understood as fabricated and not "natural". Social culture is first and foremost a quality possessed by individuals but organizations (public and private, social, political, and legal) also have cultural dimensions that might not always coincide with the individual dimension; whether people are able to make effective use of their rights in a significant way depends a great deal upon the character of the social environment as well as the culture in use by the public institutions in their place of residence, work, and life. Another word, the notions of "public culture" and "social culture" capture two main types of culture that the individual is related to besides his own culture.

\subsection{Post Cold Bar Culture}

According to Rawls, "social culture", also called the "background culture" of civil society, refers to the "culture of daily life, of its many associations, churches, and universities, learned and scientific societies, and clubs and teams"; "public political culture", in contrast, comprises the political institutions of a constitutional regime and the public traditions of their interpretation (including those of the judiciary), as well as historic texts an documents that are common knowledge. What is relevant for us is that the individual's culture may correlate with the social and public cultures, but the different cultures may also diverge in the sense that the individual does not possess the skills, observe the cultural norms, or affirm the ideological outlook currently dominating public and social institutions in society.

John Merryman long ago reminded us that historically rooted attitudes about law link the legal system to general culture. Furthermore, globalization and especially Europeanization has increased interaction between different levels of society and different countries, contributing either to convergence or to the divergence of law, affecting the formation and evolution of different legal cultures. From this viewpoint, in an article about modern legal culture, Friedman calls our time an "age of convergence in legal cultures”. Exploring six traits: change of society, density of law, instrumentality of law, position of fundamental rights, individualism and globalization, traits that link together variables of modern legal culture and shape modern legal systems, Friedman argues that greater interdependence on different levels, similar developments of industrial countries and similar demands of society have as a result in (public) attitudes towards law becoming alike. Along the years, several definitions of legal culture have been developed.

Blankenburg, for example, employs the concept of legal culture explaining where, why and when people use legal institutions, and how those institutions a key element in legal culture differ in societies. Tuori takes a multi-layered approach towards legal culture. He distinguishes the "surface level”, "national legal culture” and "deep structures of law". In his view, written laws are at the surface, like the visible lawn within a country. Underneath this lawn, and necessary for the lawn to grow and flourish, is the national legal culture. National legal culture thus functions as nutrition for written law; what he calls the "deep structures of law" are basic concepts of law, shared by many countries, like wells underneath the nutritious soil that contribute to the growing of the grass (in his metaphor, written law). Legrand focuses on the specific role of legal professionals and their mind-set (what he 
calls mentalité) to define legal culture, arguing that legal culture is the main source of division among legal systems in Europe. Instead of convergence of law, he claims, common and civil law will remain divided by an "irreducible chasm", as a British lawyer will never be fully able to step into the shoes of his German colleague because he will inevitably think differently than a German lawyer. The definition of legal culture formulated by Friedman entails better the general goal of our study, which is to reveal several understandings of the relationship between culture and human rights.

Defining legal culture as "ideas, values, expectations and attitudes towards law and legal institutions, which some public or some parts of the public holds", Friedman distinguishes between an internal and an external legal culture; while "the external legal culture is the legal culture of the general population; the internal legal culture is the legal culture of those members of society who perform specialized legal tasks.” The external legal culture is therefore a term describing public knowledge about law and attitudes towards a legal system. In reference to internal legal culture, it has been said that "anespecially important kind of group legal culture is that of legal professionals -the values, ideologies, and principles of lawyers, judges, and others working within the magic circle of the legal system”. Legal culture, as Friedman defined it, has proven to be a useful concept. However, the concept also has its critics. Some feel that the concept is too general and focuses too little on law. Cotterrell criticises the concept as too broad and not substantive enough for scholarly use to him, the study of legal culture in terms of ideas, values and attitudes of a specific group of people is too broad to distinguish it from general culture. A human rights approach to culture the human rights culture is located in the framework of a legal culture, which in its turn "fits into the broader framework of a political culture and the even broader framework of the dialectic between opinion formations and will formation in a deliberative democracy". As such, in every deliberative democracy and not only, a human rights culture merits a distinctive and, in a sense, primary place. For that reason, the next section of our article is structured in three parts. After locating the human rights culture in the broader framework of the legal culture, we explore what a human rights culture implies. That is not easy, since the term is used in the literature with hardly any definition or explanation, seeming more "like an appellative image than a concept with a properly defined meaning, which should fit and play its role.”

\subsection{Pre Cold Bar Human Rights}

Human rights activism predates the 20th century, and may include, for example, the anti-slavery movement. These movements were usually concerned with a limited set of issues, and were more local than global. One account identifies the 1899 Hague Convention as a starting point for the idea that humans have rights independent of the states that control them.

The activities of the International Federation for Human Rights (originally the International Labour Organization) founded in France by the international labour movement in the 1920's can be seen as a precursor to the modern movements. This organization was quickly embraced by the United States and European powers, perhaps as a way to counteract the Bolshevik call for global solidarity among workers.

\subsection{Post Cold Bar Human Rights}

Early in the Cold War, the "human rights" concept was used to promote the ideological agendas of the superpowers. The Soviet Union argued that people in colonized lands around the world had been exploited by Western powers. A large percentage of Soviet propaganda to the Third World cantered on charges of racism and human rights violations. The United States countered with its own propaganda, describing its own society as free and the Soviet Union's as unfree. Human rights language became an international standard, which could be used by great powers or by people's movements to make demands.

The concept of human rights was indeed built into United Nations with institutions such as the United Nations Commission on Human Rights and the Universal Declaration of Human Rights. Active diplomacy by Latin American countries was instrumental to the process of promoting these ideas and drafting the relevant agreements. As a result of this pressure, more human rights language was adopted at the 1945 San Francisco Conference to create the UN Charter. Revelations about the Holocaust, followed by the Nuremberg Trials, also had a major influence on the movement, particularly among Jewish and Christian lobbying groups. Some NGO's represented the UN charter as a victory for the human rights movement; while other activists argued that it paid lipservice to human rights while basically serving the interests of the great powers.

\section{Publicity of Culture and Human Rights}

In a speech entitled "The right to peace" in 1997 the secretary-general of UNESCO sketched an evocative picture of what we call human rights culture:

Firstly, the principle of publicity (French: publicist; German: Öffentlichkeit), in the sense that the discourse is not hidden, isolated, private, but a topic of shared concern, to which all human beings, all members of all ethnic groups, all citizens have access and in which all can participate actively.

Secondly, because of the principle of publicity, the arena of the human rights culture must be the "marketplace", "the public sphere", which includes the public that actively participates and the audience that engages in it.

As the authors notice "the marketplace nowadays is to be found in the mass media, especially the press (including opinion or forum pages) and radio and TV programs (including discussion and interactive programs)". The object of a human rights culture in principle comprises two sorts of topics, namely problems and conflicts, raised by any individual, group or community for whom a public can be found. While human rights problems refer to concrete situations that call for the application of human rights, to which end their meaning and scope have to be clarified, usually, however, the object of a human rights culture is a matter of human rights conflicts, that is "conflict arising from a clash of 
human rights, the resolution of which is assessed and regarded differently by individuals and groups”.

\subsection{Reflective Human Rights Culture}

A necessary condition for a reflective human rights culture, whose aspects of analysis, evaluation and synthesis we have indicated and whose principle, arena, object and aim we have described, is the formation of attitudes towards human rights. This is a necessary rather than a sufficient condition, for neither "a long tradition of individual liberties (as in France), nor even a deep public ,internalization of civil rights expectations (as in Britain), is a sufficient guarantee against the non-enforcement or erosion of civil rights". Yet, as a necessary condition, human rights attitudes are vitally important. If human rights are not rooted in a positive attitude, a positive mindset, positive engagement on the part of those who have to realise a human rights culture, then the entire culture of critical reflection that forms the core of it is illusory.

As the dominant approach in human rights law links culture mainly to communities and the development of a right to cultural identity, we consider that the idea of a right to culture has not been subjected to sufficiently rigorous scrutiny and some inherited positions need to be questioned. For this reason, the aim of this section is to focus on the concept of culture and its place in human rights law. Furthermore we argue that the issue of culture cannot be treated in an isolated manner, but is critical to just about every area of human rights and that a closer inspection of human rights law reveals several understandings of the relationship between culture and human rights.

\subsection{Culture is Right to Way of Life}

Annotations on the right to culture as noted in the volume Human Rights, Culture, and the Rule of Law, culture is "something that one can have a right to in the same way as one has a right to housing, clean water, or nutrition.” For example, in a recent UNESCO report, the right to culture is presented as a right to a way of life, and cultural freedom as a collective freedom, referring to the right of a group or people to follow a way of its choice.” In a similar vein, the drafters of the European Framework Convention for the Protection of National Minorities assert that the purpose of the right to culture is to protect aspirations shared by the members of a national minority "to develop their culture, and to preserve the essential elements of their identity, namely their religion, language, traditions and cultural heritage.”

\subsection{Academicians Prospective}

Among academics as well as professionals, a fundamental and radical disagreement persists not only as to what actions a right to culture may legitimise, but also about the ultimate purpose for which we want and need that right. For this reason, we believe that it is timely to redirect attention to culture when thinking about rights and justice, especially because the idea of a right to culture in its current formulation finds support among contemporary philosophers. For example, Will Kymlicka considers that the struggle for recognition of culture has been successful insofar as it has led to "a growing awareness of the importance of interests in recognition, identity, language, and cultural membership, usually ignored by liberal theorists of justice." Several philosophers argue that a right to culture really captures a set of new interests and concerns which are not well understood within the Rule of Law or the distributive paradigm. In Charles Taylor's view, such a right is supposed to protect the necessary conditions for identity-formation, the integrity or survival of the nation since "each of us depends on our national membership to enable us to develop a sense of identity." Also, more liberal interpretations of culture tend to be inspired by the nation. If pressed on the question of the nature of the social environment believed to be conducive for rights-use, liberal philosophers tend to look to the nation with its shared language and institutional arrangements. It is in this spirit that Kymlicka develops his argument about the (liberal) nation as a "context of choice" or a "cultural structure" which is of fundamental importance for making intelligent judgments about the things we want to be and do in life. The national culture is the background condition crucial for the enjoyment of agency and freedom. As Kymlicka writes:

"Our language and history are the media through which we come to an awareness of the options available to us, and their significance; and this is a precondition of making intelligent judgments about how to lead our lives. We make judgments by examining the cultural structure. What follows from this? Liberals should be concerned with the fate of cultural structures, not because they have some moral status of their own, but because it's only through having a rich and secure cultural structure that people can become aware, in a vivid way, of the options available to them, and intelligently examine their value.” Moreover, from a legal perspective, a number of culture-related interests and concerns have been gradually introduced and incorporated into the fabric of human rights law. For example, the idea of a right to culture as an individual right to take part in cultural life which was recognised for the first time in the Universal Declaration of Human Rights has been reaffirmed several times in international instruments as a right to take part in cultural life, as a right to equal enjoyment and participation in cultural activities or as a right of children to participate freely in cultural life and the arts.

\section{Principle of Equality through Human Rights Culture}

Nonetheless, given its historical significance and its multiple affirmations in international human rights law, surprisingly little interest has been awarded to the meaning of the right to cultural participation in comparison with other cultural rights. For example, when commenting on Article 15(1)(a) of the ICESCR, the UN Economic, Social and Cultural Committee only notes that the term culture should be given a wide reading, but refrains from any definition. It holds that even if culture may not seem to be a matter of human rights, it is of fundamental importance to the principle of equality of treatment, freedom of expression, the right to receive and impart information, and the right to the full development of human personality. However, it avoids engaging in any explanation of how the right to cultural participation is 
related to any of these rights. As Jessica Almqvist notes, when addressing the challenges posed by globalization on the advancement of human rights, the contributions of the committee centre on the impact of these challenges on the protection of economic and social rights, "hardly any attention being given to the impact of globalization processes on the right to culture". The modest attention paid to the right to culture as a right to cultural participation should be contrasted with the right to enjoy one's own culture. The latter right has been intensively debated from the standpoint of a diversity of different groups, such as peoples, as well as national, ethnic, linguistic, and religious minorities, including migrant workers and indigenous people as well as minority children. What is more, since its affirmation in international human rights law, the right has come to comprise a diversity of more specific rights, including the right to cultural development, the right to cultural identity and, occasionally, the right to cultural integrity. The idea of a human right to culture as connoting something like a right of a community to enjoy its own culture was launched for the first time in the context of selfdetermination rights and minority rights in 1966. In the context of self-determination, the right is essentially understood as a right of peoples to develop their cultures. Thus, according to Article 1(1) of both the International Covenant on Civil and Political Rights (ICCPR) and the ICESCR "all peoples have the right of self-determination. By virtue of that right they freely determine their political status and freely pursue their economic, social and cultural development."

\section{Social Culture is Way of Rights}

The World Commission on Culture and Development (UNESCO) has sought to endow the right to cultural development with meaning and significance. According to its findings, culture not only has an instrumental function in development, but is also a desirable end in itself, insofar as it gives meaning to our existence. Nevertheless, given its broad mandate to explore the relationship between culture and development, it fails to advance any meaningful definition of the right to cultural development as such. To sum up, the idea of a right to culture as a right to enjoy one's own culture, in particular, in the form of a right to cultural identity, is gaining momentum in human rights law, both in the form of the adoption of new instruments as well as in jurisprudence, in particular, as a right designed to protect certain minority cultures, notably indigenous peoples. In the absence of any critical account of the way in which the right to cultural identity is related to other human rights, such as the right to cultural participation, the dominant understanding of what the right to culture consists of in more concrete terms and to whom it applies is likely to remain unchallenged.

\section{Right to Equality through Social Culture}

The idea of a right to culture as a right of certain minorities, in particular, national minorities and indigenous peoples, to develop and preserve their cultural identities is gaining momentum at the expense of other cultural rights, notably the right to cultural participation. The modest attention paid to cultural rights by the various international human rights institutions mandated to expound the content and significance of those rights reinforces a deep-rooted sentiment about the irrelevance or superfluity of cultural rights. In a nutshell, culture is depicted not merely as something that everybody has a right to participate in, but also as hampering and debilitating, possibly violating the right to enjoy the rights and freedoms guaranteed in international human rights law. Nevertheless, to the extent that culture has received attention in the human rights context, it is mainly perceived as referring to community and as warranting the strengthening of the right to enjoy one's own culture or community by recognising a right to cultural identity. Other notions of culture and their significance to the advancement of human rights are left in the background.

Taking into consideration all these aspects, the current paper does not support the introduction of new or additional rights, but a more detailed account of the meaning of the existing rights and their relationship to the cultural dimension of the individual; furthermore, we articulate the ultimate purpose for which everybody needs and wants a right to culture, namely to enjoy individual freedom, considering that this is the rationale that must shape and inform the core content of an international human rights agenda on culture.

\section{Conclusion}

Concepts such as human rights culture, legal culture, political culture, civil culture and deliberative democracy do not refer to stable phenomena, unalterable products, an invariable status quo, but to an ever changing project, aimed at an ever changing process with variable input and output that will never have final substance, form or results but will always be subject to constantly changing perspectives and critical reflection.

First of all, In other words, suitable cultural equipment is not an end in itself, but is essential to the effective enjoyment of international human rights in general. A focus on culture directs attention to the fundamental importance of possessing the set of tools, skills, and know-how necessary to access laws and legal institutions as well as for participating in economic and political life.

As societies become increasingly diversified incultural terms, several issues gain critical importance for the aim of securing effective and adequate protection of individual freedom. To this end, the paper has addressed questions regarding legal culture and the role of individual culture in the human rights area. From this viewpoint, the main conclusion of the study is that human rights agenda on culture must reaffirm the universal and overarching importance of culture in advancing respect for human rights and seek to rebalance the present agenda dominated by a right to cultural identity with an urgent emphasis on the fundamental importance of "cultural equipment” and cultural infrastructure to individual freedom, as well as the need to address and specify the absolute limits to cultural difference. In so doing, the international human rights community is more likely to achieve its objective of securing a universal minimum provision of respect forpersons. 


\section{References}

[1] Almqvist, Human Rights, Culture, and the Rule of Law, 10.

[2] Howard Berman, "Introductory Note - United Nations Commission on Human Rights Sub-Commission on Prevention of Discrimination and Protection of Minorities: Draft United Nations Declaration on the Rights of Indigenous Peoples”, in International Legal Materials, 34 (1995): 541. Vienna Declaration and Programme of Action, United Nations World Conference on Human Rights, 25 June 1993, UNDoc A/CONF 157/23. Para 5 of the Vienna.

[3] Mary Ann Glendon, A World Made New: Eleanor Roosevelt and the Universal Declaration of Human Rights (New York: Random House, 2001), 221.

[4] The Executive Board, American Anthropological Association, "Statement on Human Rights" in American Anthropologist 49, no. 4 (1947): 539.

[5] Universal Declaration of Human Rights, 10 December 1948, Art 17(1), GA Res 217 (III), UN GAOR, 3rd Sess, Supp No 16, UN Doc/A/810. According to Article 17(1): "Everyone has the right to freely participatein the cultural life of the community, to enjoy the arts and to share in scientific advancement and its benefits."

[6] Robert Wuthnow, Meaning and Moral Order: Explorations in Cultural Analysis (Berkeley: University of California Press, 1987), 337-338, apud. Almqvist, Human Rights, Culture, and the Rule of Law, 41.

[7] Ann Swidler, "Culture in Action: Symbols and Strategies" in American Sociological Review 51, no. (1986): 273.

[8] Jessica Almqvist, Human Rights, Culture, and the Rule of Law (Oxford and Portland: Hart Publishing,2005), 40.

[9] Almqvist, Human Rights, Culture, and the Rule of Law, 40-46; The notion of "comprehensive doctrine" was defined and developed by John Rawls, Political Liberalism (New York: Columbia University Press, 1995).

[10] Almqvist, Human Rights, Culture, and the Rule of Law, 41.

[11] Edward B. Tylor, Primitive Culture: Researches into the Development of Mythology, Philosophy, Religion, Art, and Custom (London: Gordon Press, 1974), 1.

[12] Al Kroeber and Clyde Kluckhohn, Culture: A Critical Review of Concepts and Definitions (New York: Vintage Books, 1963 [1952]), 357. See, for example, Immanuel Kant, Lectures on Ethics (Cambridge: Cambridge University Press, 2001), 262-263.

[13] Rawls, Political Liberalism, 13-14.

[14] John Henry Merryman, The Civil Law Tradition: An Introduction to the Legal Systems of Western Europe and Latin America (Stanford: Stanford University Press, 1985), 2.

[15] Lawrence Friedman, "The Concept of Legal Culture: A Reply", in Comparing Legal Cultures, ed. David Nelken, (Aldershot: Dartmouth, 1997), 126. The debate surrounding "divergence" refers to the growth of differences between legal systems.

[16] Erhard Blankenburg, "Civil Litigation Rates as Indicators for Legal Cultures”, in Comparing Legal Cultures, ed. David Nelken, (Aldershot: Dartmouth: 1997), 34; Erhard Blankenburg, "Patterns of Legal Culture: The Netherlands Compared to Neighboring Germany", in American Journal of Comparative Law 46, no. 1 (1998): 2-3.

[17] Journal for Communication and Culture 1, no. 2 (Winter 2011).

[18] KaarloTuori, "Towards a Multi-Layered View of Modern Law", in Justice, Morality and Society: A Tribute to AleksanderPeczenik on the Occasion of His Birthday 16 November 1997, ed. Aulis Aarnio (Lund: Juristförlaget Lund, 1997), 433.

[19] Pierre Legrand, "European Legal Systems Are Not Converging", in International and Comparative Law Quarterly 45 (1996): 61; Pierre Legrand, "What Legal Transplants?" in Adapting Legal Cultures eds. David Nelken and Johannes Feest (Oxford: Hart Publishing, 2001), 65.

[20] Legrand, "European Legal Systems Are Not Converging”, 61-62, 76-78.

[21] Friedman, “The Concept of Legal Culture: A Reply”, 34.

[22] Friedman, The Legal System: A Social Science Perspective (New York: Russel Sage Foundation, 1975), 223.

[23] Friedman, The Legal System: A Social Science Perspective, 193.

[24] Friedman, The Legal System: A Social Science Perspective, 194.

[25] Roger Cotterrell, "The Concept of Legal Culture", in ed. David Nelken, Comparing Legal Cultures (Aldershot: Dartmouth, 1997), 15.

[26] Cotterrell, "The Concept of Legal Culture”, 21.
[27] Johannes A. van der Ven, Jaco S. Dreyer, Hendrik J.C. Pieterse, Is there a God of Human Rights? The Complex Relationship between Human Rights and Religion: A South African Case (Leiden/Boston: Koninklijke Brill NV, 2004), 77.

[28] Van der Ven, Dreyer and Pieterse, Is there a God of Human Rights?, 80.

[29] "The Human Right to Peace", accessed October 14, 2011, http://unesdoc.unesco.org/images/0010/001055/105530e.pdf.

[30] See Jürgen Habermas, Justification and application: Remarks on discourse ethics (Cambridge: MIT Press, 1993).

[31] Richard Rorty, "Human rights, rationality, and sentimentality", in On human rights: The Oxford Amnesty Lectures, eds. Stephen Shute and Susan Hurley (New York: Basic Books, 1993), 111-134

[32] Kirsten Hastrup, "Accommodating diversity in a global culture of rights: An introduction", in Legal cultures and human rights: the challenge of diversity, ed. Kirsten Hastrup (The Hague: Kluwer, 2001), 1-24

[33] Van der Ven, Dreyer and Pieterse, Is there a God of Human Rights?, 82-83.

[34] The point cited is illustrated by the authors with examples from two areas: the right to life and the freedom of religion; See Van der Ven, Dreyer and Pieterse, Is there a God of Human Rights?, 83

[35] Almqvist, Human Rights, Culture, and the Rule of Law, 33.

[36] World Commission on Culture and Development, Our Creative Diversity. Report submitted to UNESCO and the United Nations in November 1995 (Paris: UNESCO, 1998)Council of Europe Framework Convention for the Protection of National Minorities, Art 5.

[37] Will Kymlicka and Wayne Norman, eds., "Introduction", in Citizenship in Diverse Societies (New York: Oxford University Press, 2000), 5.

[38] Charles Taylor, "The Politics of Recognition" in Multiculturalism: Examining the Politics of Recognition, ed. Amy Gutmann, (Princeton: Princeton University Press, 1994).

[39] AvishaiMargalit and Joseph Raz, "National Self-determination" in The Journal of Philosophy 87, no. 9 (1990): 439.

[40] Will Kymlicka, Liberalism, Community and Culture (Oxford: Oxford University Press, 1989), 165.

[41] Thomas M. Leonard (2006). Encyclopedia of the Developing World: Index. A-E. Taylor \& Francis. p. 771.

[42] Clapham, Human Rights (2007), p. 27.

[43] Neier, The International Human Rights Movement (2012), pp. 7-9.

[44] Normand and Zaidi, Human Rights at the UN (2008), pp. 40-43.

[45] Normand and Zaidi, Human Rights at the UN (2008), pp. 56-57.

[46] Normand and Zaidi, Human Rights at the UN (2008), p. 57.

[47] John David Skretny, "The effect of the Cold War on AfricanAmerican civil rights: America and the world audience, 19451968", Theory and Society 27(2), 1998.

[48] Normand and Zaidi, Human Rights at the UN (2008), p. 118. "These proposals were reintroduced in San Francisco during the drafting of the Universal Declaration of Human Rights. Latin America's significant intellectual production supporting human rights is a major reason the region has been called 'the forgotten crucible' of universal human rights. Latin American jurisprudence was particularly well suited to bridging cultural divides in human rights by linking civil and political rights with economic and social rights."

[49] Neier, The International Human Rights Movement (2012), pp. 2-3.

[50] Winston E. Langley (1999). Encyclopedia of Human Rights Issues Since 1945. Greenwood Publishing Group. pp. 11-16.

[51] Normand and Zaidi, Human Rights at the UN (2008), p. 127.

[52] Normand and Zaidi, Human Rights at the UN (2008), pp. 136-138. "A few activists, in particular those whose agenda focused on racial equality and decolonization, were dismayed by the results of San Francisco. The NAACP and allied groups, which had invested significant time, resources, and hopes in using the global forum to highlight the evils of entrenched racism inside the United States and internationally, were bitterly disappointed at the outcome. To no avail, they criticized the failure to dent the vastly unequal power relations operating both between states and within their borders. Rayford Logan, civil rights activist and chair of the history department at Howard University, characterized the human rights articles in the Charter as a 'tragic joke'. But these were minority voices. Just as Roosevelt anticipated, the NGO consultants were thrilled with the role they had played in establishing the organization and fanned out across the country to spread the good news." 
[53] Langley, Encyclopedia of Human Rights Issues since 1945 (1999), p. xiv.

[54] See International Convention on Economic, Social and Cultural Rights, 16 December 1966, Art 1, GA Res 2200A(XXI), 21 UN GAOR, 21st Sess, Supp No 16, UN Doc A/6316 (1966); International Convention on the Elimination of All Forms of Racial Discrimination, 21 December 1965, opened for signature 7 March 1966, 660 UNTS 195 (entered into force on 4 January 1969); Convention on the Rights of the Child, 20 November 1989, Art 31, 1577 UNTS 44, 49 (entered into force on 2 September 1990).

[55] Journal for Communication and Culture 1, no. 2 (Winter 2011) 45.

[56] From the American Declaration of the Rights and Duties of Man (1948) and the Additional Protocol to the American Convention on Human Rights (1994) to the African Charter on Human and Peoples' Rights (1981) or the Protocol to the African Charter on the Rights of Women in Africa (2000).
[57] United Nations, Fact Sheet No 16 (Rev 1), The Committee on Economic, Social and Cultural Rights;See also R O.Keefe, "The „right to take part in cultural life. under Article 15 of the ICESCR”, in International and Comparative Law Quarterly, 47, no. 4 (1998): 904.

[58] UNESCO, Our Creative Diversity. Report of the World Commission on Culture and Development (Paris: UNESCO, 1995), 23-24.

[59] United Nations Development Programme, Human Development Report 2004. Cultural Liberty in Today's Diverse World (New York: United Nations Development Program, 2004). More interest has been offered to the right to enjoy one.s own culture from the viewpoint of minorities, indigenous populations and migrants. It is in this context that the right to culture has developed to signify a right to cultural identity and, possibly, a right to cultural integrity. 